Indonesian Journal of EFL and Linguistics

Vol. 5 No. 2, 2020

eISSN: 2503-4197, pISSN: 2527-5070

www. indonesian-efl-journal.org

\title{
Interaction Management Strategies in English Literature Lectures in Indonesian University Setting
}

\author{
Akhyar Rido \\ Universitas Teknokrat Indonesia \\ e-mail: akhyar_rido@teknokrat.ac.id \\ Heri Kuswoyo \\ Universitas Teknokrat Indonesia \\ e-mail: hery@teknokrat.ac.id

\section{Rameliya Ayu} \\ Universitas Teknokrat Indonesia \\ e-mail: arameliayy@gmail.com
}

\begin{abstract}
:
Interaction management strategies are increasingly set to become a vital factor in fostering active participants in university lectures. Following Rido, Ibrahim \& Nambiar's (2015) framework, this study investigated interaction management strategies used in English literature lectures in a university setting in Indonesia. This study employed a qualitative method and the data were gathered through video recordings. The findings showed that all literature lecturers employed three kinds of interaction management strategies such as code strategies, emotional strategies, and managing strategies. In code strategies, the lecturers used English during the entire class for clarity in opening, explanation, example, and closing. Meanwhile, in emotional strategies, the lecturers shared common strategies namely using non-verbal gestures and using humours or jokes in order to invite participation, to increase student's motivation, and to create conducive learning environment. Then, in terms of managing strategies, the lecturers decided topic, controlled or switched the topic of discussion, decided who speaks, gave direction or commanded the students, gave extended wait time, and offered opportunity for student to speak in order to enable the
\end{abstract}


Akhyar Rido, Heri Kuswoyo, Rameliya Ayu

students express their ideas and engage with the lectures. It is hoped that insights gleamed from this study will assist such lecturers to successfully manage their lectures and navigate the distribution of participation as well as content of the lesson. Keywords: English literature, interaction management strategies

\section{INTRODUCTION}

This study attempts to reveal interaction management strategies used in literature lectures in a university in Indonesia where English is used as the medium of instruction. In a university, lectures are considered the most common mode of teaching. During lectures, interaction occurs as an action in which the lecturer transfers and the students receive knowledge (Lestari, 2017; Rido, 2020a). Therefore, interaction management becomes important. Through interaction management, lecturers discover how to facilitate their students in dynamic interaction. This is salient as a key process of fostering active participation (Solheim, 2019) and, in the same time, improving communication skills (Lestari, 2017) which can create conducive learning environment (Rido, 2019).

This study is based on the premise that interaction management strategies of lecturers impact on the performance of students. In the 2008 Indonesia employer/employee survey of skills/labor demand and job vacancies involving 473 medium and large firms released by World Bank, it was reported that the Indonesian graduates' communication skill was the weakest among other demanded skills like technical and computer skills (World Bank, 2010; Di Gropello et al., 2011). One study on the incorporation of employability skills in the teaching-learning process also indicated that university graduates were strongly confident about their personal management and teamwork skills; but this was not the case with the their academic skills, especially the communication skills in English. Their poor communication skills meant they are unable to meet industries demands for competent workers and this affected their employability in the global market in future (Hendarman, 2010; Rido, 2020a).

Studies on the use of interaction management strategies in secondary and tertiary settings have widely been conducted (Amir \& Jakob, 2020; Lovorn \& Holaway, 2015; Rido et al., 2017; Rido, Ibrahim, Nambiar, 2015; Rido, 2010; Shi, 2013; Sirande, 2016). The results have shown that interaction management has been significant to promote learning and participation. Amir and Jakob (2020) state that a proper interaction management motivate students to be more active in the class. Rido, Ibrahim, and Nambiar (2015) believe that lecturers are the key factors for success learning as they are the architect of interaction who defines what to speak, who speaks, and when to stop. Here, they act as a teaching facilitator. In the same vein, Shi (2013) and Rido et al. (2017) claim that interaction management strategies used during lectures encourage students to express their feelings and thoughts comfortably as they are given opportunity to speak and ask the question. Here, critical thinking is also 
cultivated; in addition, the students experience linguistic improvements, mainly enlargement of vocabulary and enhancement of the command of technical terms. Lovorn \& Holaway (2015) suggest the use of humor during lectures as it is effective for ice-breaking which can also facilitate engagement between lecturers and students. However, Sirande (2016) reminds that lecturers must give a clear signal while giving opportunity for students to speak in order to get their attention, to make them focus, and to indicate that the lecturer welcomes their contribution.

The present study is initiated in line with those concerns. All lecturers must perform effectively and facilitate as well as give the best learning experience to their students. To this end, it is important to investigate how they manage interaction in the lectures since all decisions about interaction are influenced by them. Thus, the rese arch question is what are the types and functions of interaction management strategies used in English literature lectures in Indonesian university setting?

\section{LITERATURE REVIEW}

This study investigates interaction management strategies in English literature lectures in Indonesian tertiary setting. Interaction management is essential in the lectures and great lecturers must have distinctive interaction management strategies since they contribute to effective teaching. It is also stressed that lecturers have core roles in the lectures which beyond regulating group or pair work tasks to students. Therefore, the success of a lecture depends very much on the lecturer's ability to manage students' learning and contribution. Based on this standpoint, Rido, Ibrahim, and Nambiar (2015) classify types of interaction management strategies into three, they are code, emotional, and managing strategies as can be seen in figure 1 below.

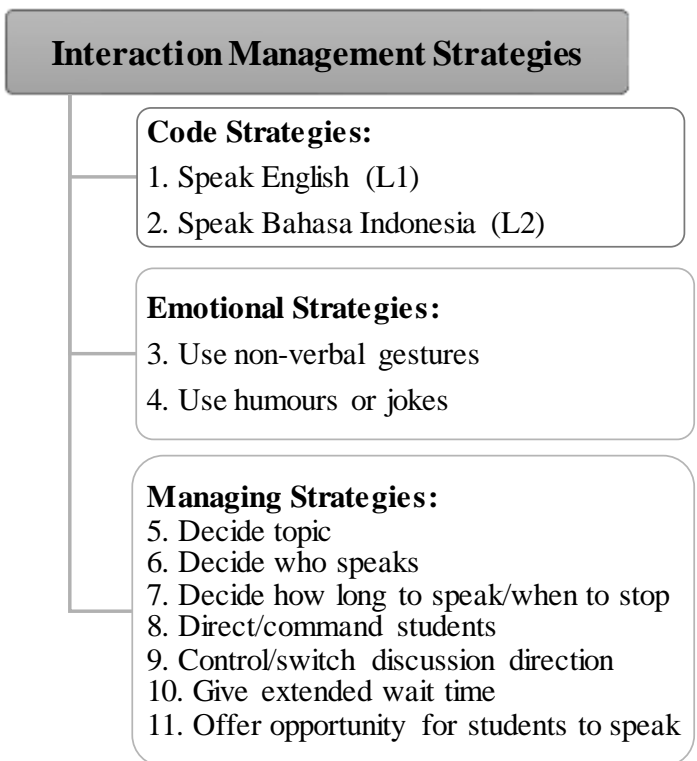

Figure 1. Interaction Management Strategies (Source: Rido, Ibrahim, Nambiar, 2015)

Indonesian Journal of EFL and Linguistics, 5(2), 2020 
First, code strategies belong to the use of language of instruction during the lecture. In the context of this research it consists of English, the official language of instruction in the lecture, and Bahasa Indonesia, the mother tongue of the lecturer and most of the students. Code strategies are important for clarity instruction, explanation, example, question, and feedback so students understand the materials at hand and engage in lectures.

Meanwhile, emotional strategies refer to gestures performed by the lecturer during the lectures. It comprises the use of non-verbal gestures such as facial expression, body language, hand gesture, and eye-contact. These also include the use of humours or jokes. The functions are to strengthen input through fulfilling students' visual needs, to emphasize statement, and to show enthusiasm so that students are attracted to the lecture. In addition, humour is to create a free-anxiety learning.

Finally, managing strategies are the roles of lecturer in managing the topic and turntaking, decide who speak, to whom, when, and how. These include deciding the topic, commanding students, controlling discussion direction, giving extended time, and offering opportunity for students to speak. The functions of managing strategies are to offer opportunity for students to think and speak, to know students personally, to make them alert and pay attention, and to be polite by calling their names.

\section{RESEARCH METHODOLOGY}

\subsection{Participants}

The participants in this study were three lecturers, Mr. Dave, Mr. Shane, and Mr. Steven (pseudonyms), who were selected purposively based on a number of criteria. The lecturers have to possess master's degree in literature, teach literature courses, obtain recommendation from head of English literature department and their colleagues, and agree to participate in this research. In addition, they must have at least five year experiences teaching prose, drama, poetry, or literary criticism in a higher education institution in Indonesia using English as the medium of instruction.

\subsection{Instruments}

The instrument employed in this study was video-recording. In a study where the researchers seek to study real people in real situations, doing real activities, videorecording can be used. There are a number of advantages to video recordings. First, video recordings improve the density of data. Second, with the moving images, video recordings are superior as the researcher gains a more complete sense of who the people are, the settings that the participants are in and the role those people play in the interactions and the types of activities they engage in the nature of these activities. In other words, video recordings not only enable us to provide information about posture, gestures, and clothing, but more importantly in discourse studies, it also accurately identifies who is speaking. Gestures, facial expressions, and other visual interactional cues also provide important information both on the negotiation of meaning and the negotiation of affect. Third, non-native speakers of English, especially those whose 
linguistic means are limited, may rely extensively on extralinguistic means, as well as linguistic and paralinguistic means, to convey both their referential message and their relational message. Fourth, this kind of visual information can help us to disambiguate verbal messages by narrowing down the possible number of accurate interpretations. Another advantage of video recording is its permanence Researcher is able to experience an event repeatedly by playing it back. With each repeated viewing, focus can be redirected to another sequence or act which may have been overlooked altogether during the earlier viewings. Replaying the event also allows us more time to contemplate, deliberate, and ponder over the data before drawing conclusions. This is important as it allows the researcher to peel off the layers of discourse for a more thorough interpretation. Finally, the visual information in videos also provides information on directionality and intensity of attention, which can be particularly useful in determining the levels of comfort and involvement of the interlocutors. These kinds of visual contextual information, then, can enrich our database in many ways (Rido et al., 2017; Rido, 2020b).

In this current study, video recordings were used to capture both verbal and non-verbal behaviors of the lecturers in relation to their interaction management strategies. It also included gestures and physical proximity between the lecturers and the students, but not accent and stress. Using a video camera on a tripod placed at the back-corner of the lecture room, this study recorded Mr. Dave's prose (LE1), Mr. Shane's drama (LE2), and Mr. Steven's literary criticism (LE3) lectures with approximately 100 minutes duration for each lecture. In total, there were three lectures with 300 minutes duration collected in this study. After that, the videos the lectures were converted into DVD versions. Then, through the DVD, the researchers could hear and watch all activities during the lectures. The lecture recordings were transcribed orthographically based on transcription conventions by Jefferson (2004) and Simpson, Lee, and Leicher (2003) using a notebook and a headset. The recordings were played repeatedly in order to get detailed transcriptions. It took about six weeks to accomplish all the transcriptions. In transforming the video-recording into a transcribed form, the details of gestures, intonations, and postures during the lecture were also noted. After all, the transcriptions were typed in a Ms. Word program in a form of table. Line numbering indicating turn-taking was given on the left of the table to ease reference and facilitate analysis. Next, peer debriefing was conducted to ensure the validity of the gathered data. A linguistic expert helped the researchers in examining the accuracy of the results of transcriptions. Member checking was also carried out as an identification process to get confirmation from the participants. After the transcriptions were neatly written, all participants verified if the transcriptions have been correctly noted. This was done to establish credibility of the data obtained.

\subsection{Data Analysis Procedures}

The data in this study were analyzed using five steps. The first step was building a database. All data gathered from video recordings were organized and labelled in 
separate files in one folder or database. Second, open-coding was done. Here, the data were studied carefully and the researchers were open to any possible categories. Third, after open-coding the data, similar interaction management strategies might be developed and the emergent themes were obtained. Fourth, after having the emerging themes, focused-coding was conducted to classify them into sub-categories. Fifth, final emerging themes were presented.

\section{FINDINGS}

This study shed new light on the interaction management strategies utilized by three Indonesian lecturers of English literature at tertiary setting. It looked at the types and functions of interaction management strategies used by the lecturers. The results showed that the English literature lecturers employed the three types of interactional management strategies proposed by Rido, Ibrahim, Nambiar (2015), namely code strategies, emotional strategies, and managing strategies. The results are presented in the following section.

\subsection{Code Strategies}

The findings demonstrated that the three literature lecturers used English in whole lectures for the clarity of instructions in the opening part, during the lecture, and in the closing part. In the following extract, Mr Dave began the lecture by using English.

Extract 1: (LE1)

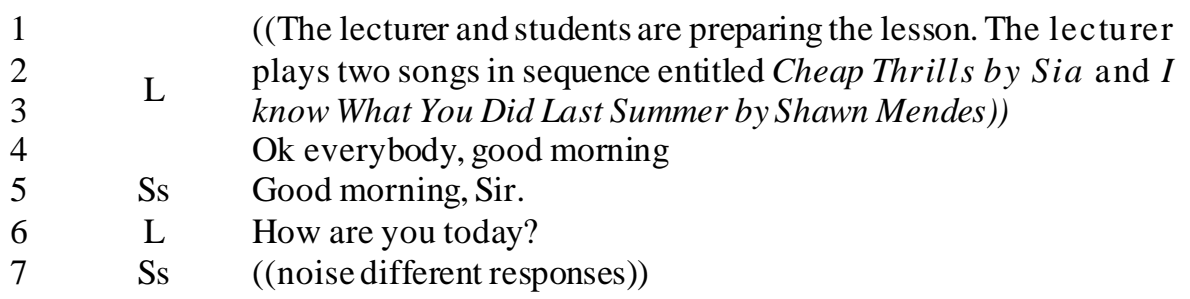

The extract above shows that Mr. Dave started the lecture with interesting way where he greeted the students and let them listen to the music first (lines 1-3). In lines 4-7, he said 'good morning' and asked their feeling. The students gave various responses of greeting (line 7).

Meanwhile, Mr. Shane started the lecture by reviewing the previous material given. A few lines from extract 2 below indicated that he also used English.

Extract 2: (LE2)

5 Ok, today, we are going to continue the materials ya. Ee little bit -

6 L a little bit review related to what we have already discussed

$7 \quad$ previously. Previously, we have already ((move and walk to left

8 side) $)($.) ee discuss about what is fiction.... 
In drama lecture, Mr. Shane tended to start the lecture by reviewing what had been discussed in the previous session, about fiction (lines 5-8). He wanted to ensure students' understanding before continuing to the next material; therefore, he revisited what fiction was.

Similarly, in literary criticism lecture, Mr. Steven opend his lecture using English by greeting the students. Extract 3 below is presented as the data sample.

\section{Extract 3: (LE3)}

$\begin{array}{lll}1 & \text { Good to have you today, this evening and this number, I wish that } \\ 2 & & \begin{array}{l}\text { you're good, I'm good. And some of your friends, they're very } \\ \text { busy to prepare for Saturday night program. I hope everybody }\end{array} \\ 4 & \text { L } & \begin{array}{l}\text { support that even though you're not there but give your support in } \\ 5\end{array}\end{array}$

In the above extract, Mr. Steven began the lecture by greeting the students and hoping that they were doing well, indicating that he gave more attention as he understood that the students had to attend the lecture in the evening, on Saturday night (lines 1-3). He also encouraged his students to support their friends who conducted an event (lines 45).

Furthermore, English was also used during the main part of the lectures, while explaining the materials. It can be seen in extract 4 below.

Extract 4: (LE1)

392

393

394

395

396

397

398
Ok, the proof, the action. Eventhough I don't- I never say that I am diligent, when- when action shows it, so you may believe it. Indirect characterization shows things that reveal the personality $\mathrm{L}$ of the character. There are five different methods of direct characterization. Five methods, five, five., five, five. Number one is, you remember about STEAL? Ok, STEAL- speech, thoughts, effect on others towards the characters, action, and looks

Mr. Dave was explaining the material concerning characterization. First, he talked about undirect characterization (lines 392-395). After that, he discussed direct characterization and highlighted a term STEAL (speech, thought, effect, action, and look) which was done in order to ease the students memorizing direct characterization (lines 396-398).

Mr. Shane explained his materials using English as well. A few lines from extract 5 below in drama class illustrate this strategy.

Extract 5: (LE2)

55

56

57

58

59
(3.2) alright! Because to discuss character, it can not be separated from its characterization. (1.9) So talking about characters-

L alright- we do not only talk about the individual itself but also its characterization- in sense ( ) Stenton also said charactercharacterization is character as well. (2.4) So character refers two 
Akhyar Rido, Heri Kuswoyo, Rameliya Ayu

$\begin{array}{ll}60 & \text { things actually (1.6) ya- (the individual who appears inside the } \\ 61 & \text { story) or its characterization. So, I hope that later on ee- }(0.5) \text { we } \\ 62 & \text { can be very familiar with this terminology ya- so whenever I say } \\ 63 & \text { character }{ }^{\circ} \text { oke }^{\circ} \text { doesn't mean that it's only like the individual but } \\ 64 & \text { also its characterization also, ok. }\end{array}$

Here, Mr. Shane used English when he was discussing character and characterization with the students. First, he introduced the terminolgy 'character and characterization' to the students (lines 55-57). Second, he scoped it by citing a statement from a scholar 'Stenton' (lines 56-59), continued by emphasizing that the students had to be familiar with the terminology (lines 60-64).

Apart from in explaining the material discussed earlier, Mr. Steven also used English in the lecture. It can be seen in extract 6 below.

\begin{tabular}{|c|c|c|}
\hline \multicolumn{3}{|c|}{ Extract 6: (LE3) } \\
\hline 132 & & Yeah, literature, literary work can move people, right, can change \\
\hline 133 & & the way their thinking, that is true, but quiet often we don't realize \\
\hline 134 & & about that, ok because we also do not like to read literature anyway, \\
\hline 135 & & ok, that what makes us do not understand its function, but if you \\
\hline 136 & $\mathrm{~L}$ & look at that.. You know you look at someone's biography and \\
\hline 137 & & expect to see how they solve their problem, how they build \\
\hline 138 & & something, ok, you see how the story ee history happened through \\
\hline 139 & & historical book, but literature also give you that portrayal and, \\
\hline 140 & & probably it gives more realistic portrayal because it was written by \\
\hline 141 & & somebody inside or within society. \\
\hline
\end{tabular}

Mr. Steven gave an explanation about literary work to the students. In lines 132-134, he began to talk about the functions of literary work to someone's life along (line 132 135) with giving an example of biography (lines 136-137). He continued explaining how historical book and literature could also give realistic portrayal of someone within society (lines 138-141).

Furthermore, English was also used in the closing part of the lecture. The example is presented in extract 7 below.

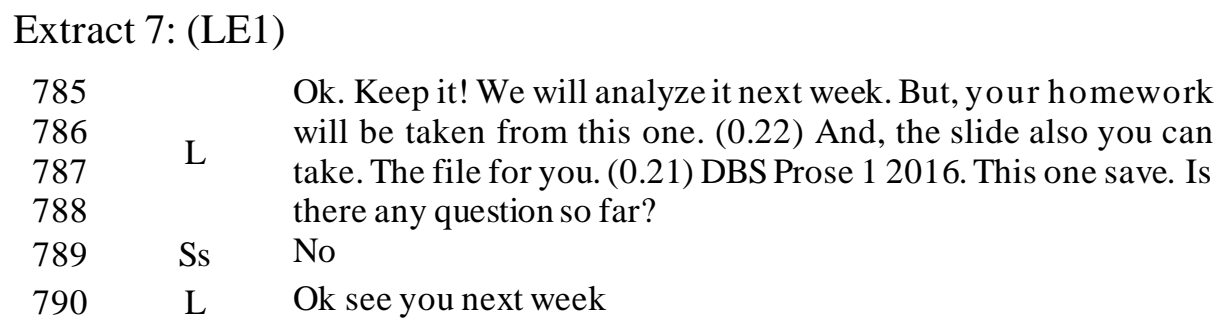

Before closing the lecture, in lines 785-787, Mr. Dave gave an assignment to the students. Here, he firstly ensured that students understood the materials at hand. Thus, he offered the students to ask question 'is there any question so far' (lines 787-788). 322

Indonesian Journal of EFL and Linguistics, 5(2), 2020 
The students responded by saying 'no' (line 789), indictaing that everything was clear. So, in line 790, he closed the lecture by saying 'ok see you next week'. All of his closing parts were done in English.

Same as the previous extract, Mr. Shane gave the students an assignment before the lecture ended. The utterance can be seen in extract 8 below.

Extract 8: (LE2)

$\begin{array}{lll}851 & & \text { It is easier and cheaper, you know! You don't need to- to spend } \\ 852 & & \text { electricity and energy (). (0.12) But, make sure your hand writing is } \\ 853 & \text { L } & \text { readable ya. If it is not, then learn how to make people ee(.) } \\ 854 & & \text { understand your hand writing. Ok, no more question ya? I think that's } \\ 855 & & \begin{array}{l}\text { all ya for today. Thank you very much ya. See you. } \\ 856\end{array} \text { Ss } \quad \begin{array}{l}\text { See you Sir }\end{array}\end{array}$

At the end of the lecture, by using English, Mr. Shane told the students that the assignment must be submitted by hand writing (lines 851-853). After ensuring that there was no question from the floor (line 854), he completely closed the lecture by saying 'thank you very much ya. See you' (line 855 ) and the students replied by saying 'see you sir' (line 856).

Unlike other lecturers, Mr. Steven immediately finished the lecture without giving an assignment. It can be seen in extract 9 below.

Extract 9: (LE3)

1138 L Everyone thank you for coming, see you next meeting with your

1139 quiz, see you, assalamualaikum warahmatullahi wabarakatuh

While closing the lecture, Mr Steven reminded that the students would have quiz in the following meeting. He, then, signed the end of the lecture by saying 'everyone thank you for coming, see you next meeting', continued by Islamic salaam (lines 11381139).

\subsection{Emotional Strategies}

This study also found that all lecturers employed emotional strategies. The use of emotional strategies by the lecturers will be presented in the following section.

\subsubsection{Use Non-Verbal Gestures}

Using non-verbal gestures generally deals with body language and hand gesture. Extract 10 indicated that Mr. Dave used body language during the lecture.

Extract 10: (LE1)

536

537

538

539
Ok, thank you. Next, goes to the man. Yes, man. Lady ((point a

L group of male students)), the man ((point a group of female students))

Ss $\quad(($ laugh $))$

Indonesian Journal of EFL and Linguistics, 5(2), 2020 
Akhyar Rido, Heri Kuswoyo, Rameliya Ayu

$\begin{array}{lll}540 & \text { L } & \begin{array}{l}\text { We have to change actually (.) lady ((point a group of female } \\ \text { students)) and the man ((point a group of male students)). }\end{array} \\ 541 & \text { Ss } & ((\text { laugh }))\end{array}$

While lecturing, Mr. Dave realized that there were two groups of male and female students by pointing them out (lines 536-538). So, in order to grab their attention and to ensure that he gave equal opportunities for all the students to contribute instead of gender, again by pointing his finger, he told the students that he had to change the turntaking, firstly female (line 540), then male students (line 541). This visual bodygesture helped the students to understand what he meant.

Meanwhile, the following extract proofed that Mr. Shane's lecture used body language while presenting the material.

Extract 11: (LE2)

256

257

258

259

260

261

262

263

264
... ((Look at the screen)) But right now, it's no longer like that. ${ }^{\circ} \mathrm{ok}^{\circ}$. One character only has ee(.) one function. Right now, it can be both. So that's why we need-we need you- ((look at the

$\mathrm{L} \quad$ screen) $){ }^{\circ} \mathrm{Ok}^{\circ}$ to analyze that. But you need to know the parameter first- ${ }^{\circ} \mathrm{Ok}^{\mathrm{o}}$ - you need to know the parameter first. If protagonist character is the one who is being given sympathy and empathy. ((look at the screen) $)$...

S Sir ((raise hand))

L Yes. ((approach the chair))

Before line 256, Mr. just started explaining types of character using power point slides so he looked at the screen. He, kept continuing his explanation about reasoning of analyzing characters and the parameter (lines 257-262), again looked at the screen (lines 258 and 262). This was done in order to make the students pay attention and read his presentation slides on screen. In responding his explanation, a student raised his hand, asking a question (line 263). He said 'yes' and approached the student's chair, indicating that he allowed him to speak (line 263).

Furthermore, in this following extract 15, Mr. Steven used his head gestures while lecturing activity.

Extract 12: (LE3)

1015 In producing literary work, ok, in the theory in the literary work, so

1016 we just analyze the literary work in it's e treated it as au tonomous

1017 L creation, do you understand what Imean? Seem like you say ((nod

1018 head)) but ((shake head)), say no if it is not because it will be your

1019 quiz right? Ok, Hari ok?, ok Masdar?

Mr. Steven was explaning literary production in relations to theory in literary works (lines 1015-1016). Then, he made confirmation check by asking the entire floor 'do you understand what I mean?' (line 1017) as he noticed some students' confusing 
reaction. Then, he imitated them by nodding and shaking his head (lines 1017-1018). After that, he emphasized that his explanation would be important for thier next quiz and mentioned names of the students who made the reaction (lines 1018-1019). This indicated that he also read the students' body gestures during the lecture.

\subsubsection{Use Humours or Jokes}

In the next strategies, the lecturers used humour or joke during lecture activities. Interestingly, they did it in different ways and in different activities. Some examples are presented in the following extracts.

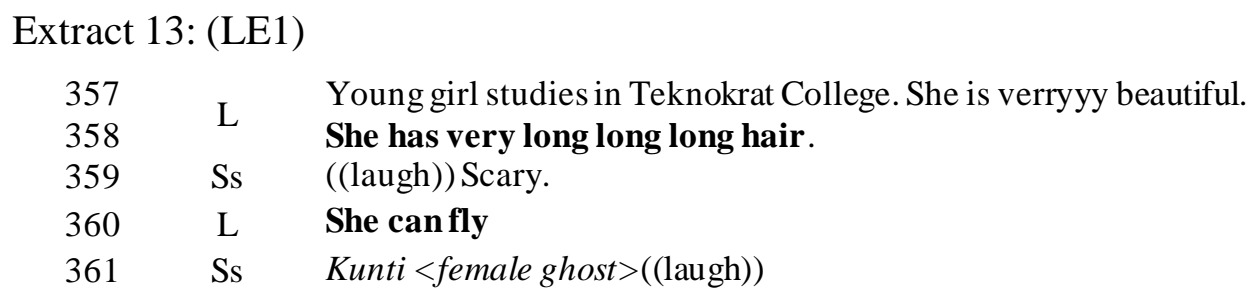

Mr. Dave was explaining material about developing character and characterization in prose lecture. In lines 357-358, he mentioned a young female character who had long hair (lines 357-358). It made the students laugh, but said 'scary' (line 359). He continued the description by saying that the character could also fly (line 360). After that, the students responded "kunti <female ghost >" and laughed together (line 361), indicating that it sounded funny for them.

Meanwhile, Mr. Shane used a humour while one of the students asked permission to go to restroom. It is seen in extract 14 below.

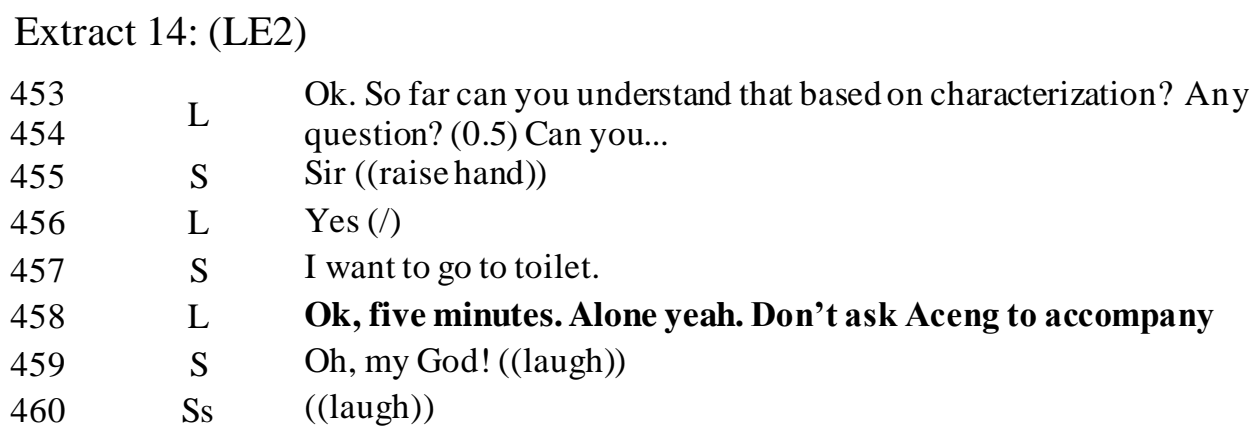

During the lecture, Mr. Shane offered the students an opportunity to ask question (lines 453-454). Suddenly, there was a student interrupted and raised his hand (lines 455457). The lecturer said 'yes', indicating that he allowed the student to say something. However, the student stated that he just wanted to go to toilet. Responding that, the lecturer teased the student not to ask his friend to accompany him (line 458). Realizing that it was a funny joke, in lines 459-560, the students laughed. 
Mr. Steven had his own style in using a humour in the lecture. The sample of data can be seen in extract 15 below.

\begin{tabular}{|c|c|c|}
\hline \multicolumn{3}{|c|}{ Extract 15: (LE3) } \\
\hline 1045 & $\mathrm{~L}$ & Psychology, do you understand? Meanwhile the objective just \\
\hline 1046 & & treating this literary work as autonomous body, for example if it is a \\
\hline 1047 & & picture of cat ((draw something in whiteboard $))(.5)$ this is cat \\
\hline 1048 & Ss & $(($ laugh $))$ \\
\hline 1049 & $\mathrm{~L}$ & This is cat \\
\hline 1050 & Ss & $(($ laugh $))$ \\
\hline 1051 & $\mathrm{~L}$ & This is cat, ok \\
\hline 1052 & Ss & $(($ laugh $))$ ayam <chicken> \\
\hline 1053 & $\mathrm{~L}$ & Why? Oke, chicken ya chicken. This is chicken, ok, no, listen, why \\
\hline 1054 & & you said this is chicken... \\
\hline
\end{tabular}

While explaining 'literary work as an autonomous body' to the students, he gave example by drawing something on whiteboard and said 'this is cat' (lines 1045-1047). The students suddenly laughed after seeing the picture (line 1048). He kept insisting that it was a cat (lines 1049 and 1051) and this made the students even laughed harder (line 1050) because they thought he drew a chicken (line 1052). In lines 1053-1054, he still questioned why the students thought it was a chicken. This made the room full of laughter.

\subsection{Managing Strategies}

The findings revealed that all lecturers employed common strategies namely deciding topics, directing or commanding students, controlling or switching discussion direction, giving extended wait time, and offering opportunities for students to speak.

\subsubsection{Decide Topic}

The following strategies belong to decide topic by the lecturers. In extract 16, the data showed that Mr. Dave introduced topic in the beginning of the lecture.

Extract 16: (LE1)

$\begin{array}{lll}75 & \text { L } & \text { It is what we are going to study. We are going to focus ont } \\ 76 & \text { character and }(/) \\ 77 & \text { Ss } & \begin{array}{l}\text { character and characterization } \\ 78\end{array} \\ 79 & & \begin{array}{l}\text { Yes. Ok, so we will talk about what is character and } \\ \text { characterization- whether it is real or not so you can try to proof }\end{array} \\ 80 & \text { L } & \begin{array}{l}\text { it later. So this is one, as- as Ihave told you that we are going to } \\ 81\end{array} \\ 82 & & \begin{array}{l}\text { scope of our study- is not only talking about character and } \\ \text { characterization but here theme, plot, setting, point of view, and }\end{array} \\ 83 & & \text { language style- it will be ee discussed later in the next meeting. }\end{array}$

In lines 75-76 and 78-79, right after opening the lecture, he mentioned that he wanted to discuss character and characterization. Besides that, he also told some topics for the 
next discussion so that the students could relate them with the current topic (lines 81 $83)$.

Along the same vein, Mr. Shane mentioned topic in the opening part of his lecture.

\section{Extract 17: (LE2)}

$\begin{array}{lll}15 & \text { ok. nah, starting from today ee (.) we are going to continue the } \\ 16 & \text { L } & \text { materials, ok, ee (.) starting from the story fact of intrinsic elements } \\ 17 & & (0.5) \text { that exist, ok, inside of those kind of fictions. (1.6) Ok, this } \\ 18 & \text { particular material ee-((move his position to right side)) maybe until } \\ 19 & \text { next meeting also ya- we will deal with characters. }\end{array}$

Mr. Shane brought the students to understand that they were discussing intrinsict element of fictions (lines 15-17). After that, he emphasized by telling the students that the focus would be on characters until the following meeting (lines 18-19).

Meanwhile, in extract 18 , Mr. Steven clearly decided all the topics and told it to the students.

\section{Extract 18: (LE3)}

11

12

13

14

15

16

17

18

19
This is our agenda today, match day 3, meeting 3. Today, first we'll review about last meeting materials, ok limited to the discussion of why literature does matter?, ok, everybody agreed at that time, literature does matter, please refresh our understanding, or our mind, and then we define "what is literary criticism", after that

L meeting two we discuss about approach and theory.. most particularly in the literature analysis, and the last one based on our agenda we discuss about M. H. Abrams critical orientation to literature, ..

In the beginning of the lecture, Mr. Steven reviewed the previous material; first, why literature does matter, (lines 11-14). After that, he revisited 'what literary criticism is' (line 15). Then, in lines 18-19 he introduced topic for the particular meeting, 'Abram's crticial orientation to literature'.

\subsubsection{Decide Who Speak}

After deciding topic, the lecturers also decided who speak during the lectures. In the extract, Mr. Dave called on a specific student to speak.

\section{Extract 19: (LE1)}

$\begin{array}{lll}91 & & \text { But, this is so special. Because of what? Because you will really } \\ 92 & \text { L } & \begin{array}{l}\text { really analyze and apply it (.) not only inside of story, but you can } \\ \text { also apply it in the reality. Do you have someone special in your }\end{array} \\ 93 & & \begin{array}{l}\text { life, in this class? ((ask a female student)) } \\ 94\end{array} \\ 95 & \text { S } & \begin{array}{l}\text { Oh, ya- yes. } \\ 96\end{array} \\ 97 & \text { L } & \begin{array}{l}\text { Yes ((smile)) Ok. Keanu (.) do you have special... friends in this } \\ \text { class? }\end{array}\end{array}$


Akhyar Rido, Heri Kuswoyo, Rameliya Ayu

$98 \quad \mathrm{~S} \quad$ Yes.

In extract 19 above, Mr. Dave was explaining how to analyze story which could be applied in reality as well (lines 91-93). After that, he asked a female student about someone special in her life (lines 93-94), then, posed a display question to another student named Keanu (lines 96-97), indicating that he wanted the students to speak. Responding the questions, the students gave their short answer 'yes' (lines 95 and 98).

In different lecture, Mr. Shane nominated a female student to answer his question. The sample of the data can be seen in extract 20 below.

Extract 20: (LE2)

\begin{tabular}{|c|c|c|}
\hline 19 & $\mathrm{~L}$ & Enough ya (.) so Alleta \\
\hline 2 & S & Yes sir \\
\hline & $\mathrm{L}$ & $\begin{array}{l}\text { What about you? What do you know about Agus? ((walk to the } \\
\text { left and approach Alleta)) }\end{array}$ \\
\hline & $S$ & $\begin{array}{l}\text { Agus is- hhhmm... humble person, ee like to talk too much, } \\
\text { sometimes, and-and full love humor. }\end{array}$ \\
\hline
\end{tabular}

In lines 19 and 21-22, after explaining his material, Mr. Shane selected a female student, Alleta, and posed a referential open question about her friend, Agus. This indicated that he wanted her to speak her mind. After that, she shared to everyone that Agus was a down-to-earth, talkative, and humorous person (lines 23-24).

Similarly, Mr. Steven also gave opportunity for his student to speak during the lecture.

Extract 21: (LE3)

\begin{tabular}{|c|c|c|}
\hline 86 & & And now we look at this and come to our first agenda reviewing \\
\hline 87 & & last material discussion "why literature does matter?" Last time \\
\hline 88 & $\mathrm{~L}$ & some of you responded literature does matter because a, b, c. I war \\
\hline & & you to refresh what we have discussed last time, anybody can sh \\
\hline & & ok ((point a student)) Ratna $(/)$ \\
\hline
\end{tabular}

Mr. Steven was revisiting previous material with the students in the beginning of the lecture 'why literature does matter?' (lines 86-88). Therefore, he wanted the students to give their thought, then nominated a student named Ratna (lines 89-90). Here, he actually wanted to ensure that the students have understood the materials at hand before continuing to the next discussion.

\subsubsection{Direct/Command Students}

The results also showed that the lecturers directed and commanded students during the lecture. The way Mr. Dave employed the strategy can be seen below.

Extract 22: (LE1)

99 L But today's discussion we are going to talk about character and 
100

101

102

103 characterization. So, emm (.) write done one of the name our

friend over here ((pass a board marker to one student and tell her to write on the whiteboard))

S ((come to the front and write on whiteboard))

In the lecture, Mr. Dave was discussing character and characterization with the students (lines 99-10). So, he gave instruction to a student to write one of her friend's name on the whiteboard (lines 100-102). After that, the student came to the front and wrote something on the whiteboard, indicating that she listened and followed the instruction.

Mr. Shane also gave command to his student during the lecture. A few lines from extract 23 below illustrate this strategy.

Extract 23: (LE2)

43 L Who is that? ((walk to the door and look out)) (.) Putri Diana

44 would you please to help me-( ) help me okay (.) alright, see them

$45 \quad \mathrm{~S} \quad$ Yes. ((stand up and walk out through the door))

46 L See them and let's say bye bye

In lines 43-44, Mr. Shane noticed that somebody knocked the door while he was just started the lecture; therefore, he instructed a female student (Putri Diana) to see the person. The students followed the instrution and walked out through the door (line 45). After realizing that there was few students who came late, he told Putri Diana to tell them that they were not allowed to attend the lecture (line 46).

In addition, Mr. Steven also commanded his students in the lecture. The example is presented in extract 24 below.

\section{Extract 24: (LE3)}

\begin{tabular}{|c|c|c|}
\hline $\begin{array}{l}25 \\
26\end{array}$ & $\mathrm{~L}$ & $\begin{array}{l}\text { Ok, first of all will give an example to give the clear understanding } \\
\text { to literary criticism, an example, ok }\end{array}$ \\
\hline 27 & & Can everybody give applause for Devi? \\
\hline 28 & Ss & $(($ applause $))$ \\
\hline 29 & $\mathrm{~L}$ & Very pleased \\
\hline & $S$ & $\begin{array}{l}\text { ((signal with finger to ask where she should stand to present her } \\
\text { thought)) }\end{array}$ \\
\hline & $\mathrm{L}$ & $\begin{array}{l}\text { Up to you, you want to stand here, sit here, up to you, can you just } \\
\text { go to the front, no no no you cannot sit there, ok, go to the front } \\
\text { and share idea }\end{array}$ \\
\hline
\end{tabular}

Mr. Steven was discussing literary criticism with the students and he wanted one of the students to give an ecample (lines 25-27). However, the student gave a signal with her finger, indicating that she was unsure from where she had to stand and talk (line 30). Then, the lecturer instructed her to come to the front, instead of sitting on her chair (lines 33-34). 
Akhyar Rido, Heri Kuswoyo, Rameliya Ayu

\subsubsection{Control/Switch Discussion Direction}

The next managing strategies are controlling/switching direction of discussion. In extract 25 below, the lecturer utilized the strategy during the lecture.

Extract 25: (LE1)

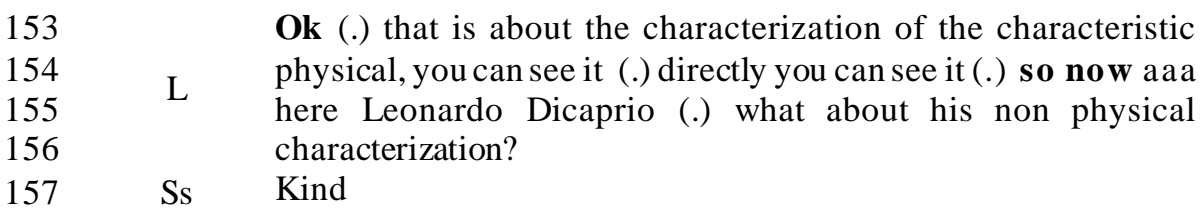

In the above extract, Mr. Dave was discussing character and characterization. In line 153, he used discourse markers 'ok' folowed by 'that is about the characerization', indicating that the discussion was done. After that, the lecturer used another discourse markers 'so now' (line 154), continued by a statement ' here is Leonardo Di Caprio' and a qustion 'what about his non physical characterization?' to the entire class (lines 155-156), showing that he wanted to continue and invited the students for further discussion. In line 157, the students gave their response 'kind'.

Meanwhile, the way Mr. Shane controls the discussion direction can be seen in extract 26 below.

Extract 26: (LE2)

\begin{tabular}{|c|c|c|}
\hline 108 & & Ok, full of humor. Ok. So that's the thing So Agus- alright- can \\
\hline 109 & & not stand alone. (0.5) sometimes if somebody asks you. Eh (.) do \\
\hline 10 & & you know Agus? Yes, the one who is tall, $(0.5)$ who is funny. \\
\hline 111 & & Alright (.) so that's the things. So, that's why I say this is related. \\
\hline 112 & $\mathrm{~L}$ & So whenever later on- ya-you analyze character, ok. You will also \\
\hline 13 & & see the characteristic of it. What makes one character different with \\
\hline & & another character. Ok (.) Nah, and how to analyze that? (.) In \\
\hline & & general, ya, there are four classifications of characters $(0.3)$ you \\
\hline 16 & & need to analyze each of them \\
\hline
\end{tabular}

Mr. Shane was talking about character and characterization during the lecture and he agreed with one of the student's response that said his friend was full of humour, then, switched the discussion direction which was indicated by the use of discourse markers 'so, that's the thing'(line 108). Next, he added an explanation about the relations between character and characterization (lines 109-110), followed by dicourse markers 'alright (.) so that's the thing' (line 111), indicating that he finished with the explanation and was ready to move to the next discussion. After that, by utilizing discourse markers 'so' (line 112) and 'ok (.) nah' (line 114), he directed the students to the next discussion which was about 'how to analyze a character' and 'four classification of characterization' (lines 114-116)

In the next extract, Mr Steven also controlled the discussion direction during the lecture. 


\section{Extract 27: (LE3)}

250 L Ok, thank you. Other things? Done already? Enough? Ok, we literary criticism.. Ee, Devi has given us three, right? Three examples. Ee the category is clear anyway, you, ee, what's literary criticism? This is actually a discipline, you know a discipline? A path, ok, a science, ok, of applying theoretical principle of the..

In line 250, Mr. Steven thanked his student who just gave her opinion and examples towards the previous material 'literary criticsm and its category'. After that, he moved to the next discussion. So, he used discourse markers 'ok' and said 'we proceed' to indicate the trasition (lines 250-251), followed by a summary that literary criticism is a discipline of science (lines 252-255).

\subsubsection{Give Extended Wait Time}

The findings also revealed that all lecturers gave extended wait time. The examples can be found in the following extract.

\section{Extract 28: (LE1)}

$\begin{array}{lll}733 & & \text { Ya that's the explanation. (0.22) So, after you analyze it, you will } \\ 734 & \text { L } & \begin{array}{l}\text { see whether all elements or not- or there are some part of STEAL- } \\ \text { STEAL ((pronunciate it with Indonesian language) }) \text { STEAL in } \\ 735\end{array} \\ 736 & & \begin{array}{l}\text { that point. (5.22) Finish }(/) \\ 737\end{array} \\ 738 & \text { S } & \begin{array}{l}\text { Not yet } \\ \text { Three more minutes. }(0.33)\end{array}\end{array}$

During the lecture, Mr. Dave gave the students a task, analyzing character and characterization using 'STEAL' element (lines 733-735). After few minutes, he checked the progress by asking a question 'finish (/)' (line 736) and the students responded by saying 'not yet' (line 737), indicating that they had not finished the analysis. Understanding the situation, he gave extended wait time by saying 'theree more minutes' (line 738).

In drama lecture, Mr. Shane also gave extended wait time to the students. His utterance can be seen in extract 29 below.

Extract 29: (LE2)

$\begin{array}{lcl}735 & \text { L } & \text { Ok. Any other? (.5) ((wait for response)) } \\ 736 & \text { Ss } & ((\text { silence })) \\ 737 & \text { L } & \text { Time is almost over } \\ 738 & \text { Ss } & \text { No sir }\end{array}$

Before closing the lecture, in line $735, \mathrm{Mr}$. Shane tried to summarize the lecture. He asked if the students had questions and gave them time to think (line 735). As it was just no response, just a slience (line 736), he reminded them by saying 'time is almost 
over' (line 737), indicating that he still waited and gave the students opportunity to ask. A choir of students responded 'no sir', indicating that everything was clear and the lecturer could end the lecture.

In the same vein, extarct below shows how Mr. Steven gave extended wait time to the students in his lecture.

Extract 30: (LE3)

$\begin{array}{lll}866 & \text { L } & \text { Next, may be .. I choose } \\ 867 & \text { S } & \text { Masdarsir } \\ 868 & \text { L } & \text { Ok, Masdar. Masdar two minutes please think and share to us } \\ 869 & & \text { here, prepare two minutes }\end{array}$

In the lecture, Mr. Steven wanted his students to present their thought about the materials at hand and he ended up by nominating a student (lines 866-868). Noticing that the student needed time to share his standpoint; therefore, he gave him two minutes (lines 868-869).

\subsubsection{Offer Opportunity for Students to Speak}

Based on the results of this study, all lecturers offered opportunity for the students to speak. The data sample can be seen in the following extract.

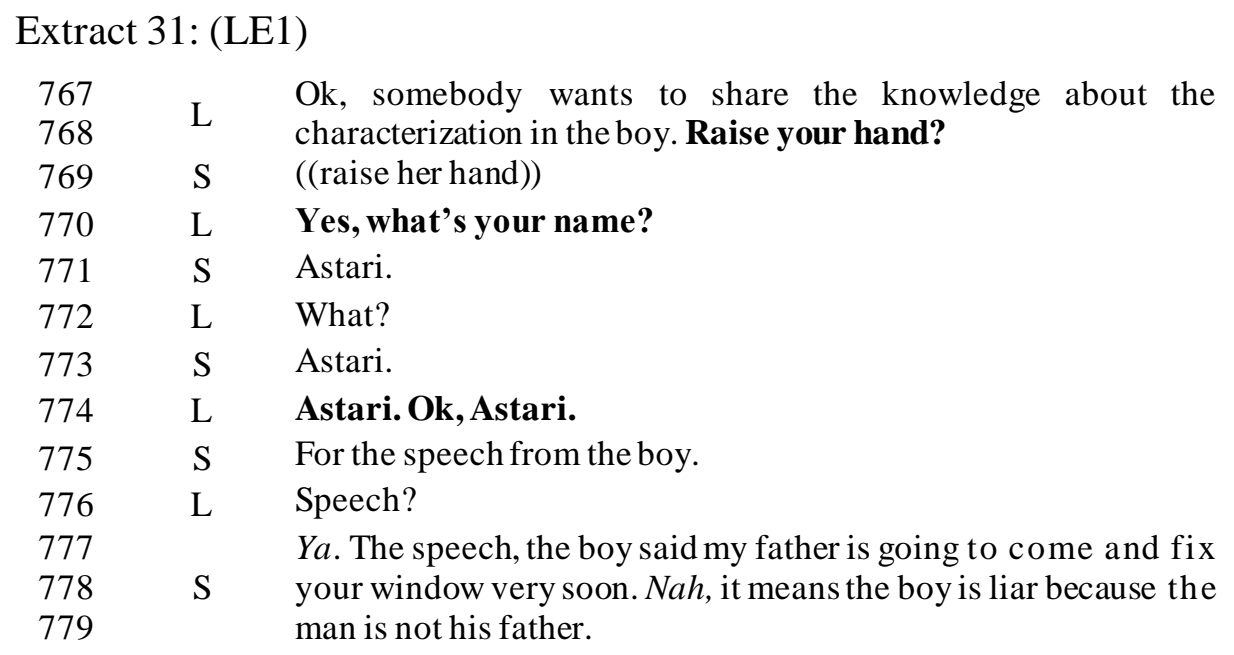

In extract 31, Mr . Dave was discussing character and characterization during the lecture and he offered the students to give their opinion (lines 767-768). A student initiated by raising her hand (line 769) and he allowed her to talk (line 774). First, the student mentioned that she wanted to talk about 'speech from the boy' (line 776). After that, she gave her elaboration (lines 777-779).

Next, in data sample below, Mr. Shane also gave opportunity for the students to speak through initiating questions. 


\begin{tabular}{|c|c|c|}
\hline \multicolumn{3}{|c|}{ Extract 32: (LE2) } \\
\hline 246 & $\mathrm{~S}$ & $\operatorname{Sir}(/)(($ a student raises his hand $))$ \\
\hline 247 & $\mathrm{~L}$ & $\operatorname{Yes}(/)$ \\
\hline $\begin{array}{l}248 \\
249\end{array}$ & $S$ & $\begin{array}{l}\text { How about the character who make- who make ee conflict but in } \\
\text { the- in the end of the story they-they solve- their problem? }\end{array}$ \\
\hline 250 & $\mathrm{~L}$ & They solve their problem themselves? \\
\hline 251 & $\mathrm{~S}$ & Yes \\
\hline 252 & & They solve their problem themselves. Then still- still- ok- still it is \\
\hline 253 & & antagonist character. Later on we discuss ya- later on we discuss \\
\hline 254 & $\mathrm{~L}$ & after this maybe ((pointing out the screen). Related to the \\
\hline 255 & & development (0.5) of the character inside of the story because \\
\hline 256 & & sometimes character also develops based on the flow of the plot \\
\hline 257 & $S$ & $\operatorname{Sir}(/)(($ a student raises her hand $))$ \\
\hline 258 & $\mathrm{~L}$ & $\operatorname{Yes}(/)$ \\
\hline $\begin{array}{l}259 \\
260\end{array}$ & S & $\begin{array}{l}\text { Is there any character that ee }(.) \text { they have both of them } \\
\text { characters? }\end{array}$ \\
\hline 261 & & 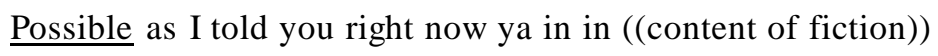 \\
\hline 262 & $\mathrm{~L}$ & fiction- ee (.) we can not close any possibllities because right now \\
\hline
\end{tabular}

Mr. Shane's lecture was dominated by question and answer activities, especailly when he discussed about antagonist and protagonis character with the students. In lines 246 and 257, two students raised their hand, indicating that they initaited to talk. In lines 247 and 258, the lecturer responded by saying 'yes (/)' signaling that he allowed them to speak. Then, they posed their open-referential (lines 248-249) and display questions (lines 259-260). Mr. Shane gave his response in lines 252-256 and 261-262.

In the following extract, this study found a student raised hand to give ideas in $\mathrm{Mr}$. Steven's lecture.

Extract 33: (LE2)

\begin{tabular}{|c|c|c|}
\hline 338 & & Ok.. approach, theory, what's make them different especially in \\
\hline $\begin{array}{l}339 \\
340\end{array}$ & $\mathrm{~L}$ & literary analysis, literary criticism.... Yes ... Feel free, speak \\
\hline 341 & $\mathrm{~S}$ & $(($ raise hand $))$ \\
\hline 342 & $\mathrm{~L}$ & Rani \\
\hline 343 & & As I read the.. Some .. Some source, literary theory is the prelude \\
\hline 344 & & the relation between author and the work, and in some approach, \\
\hline 345 & & there are sociological criticism which focus on the cultural, \\
\hline 346 & & economy, and political context, and the second is mytho.. \\
\hline 347 & $\mathrm{~S}$ & mythological criticism is emphasis the psychology and history of \\
\hline 348 & & the work, and the reader response is how, in this case , its.. it is \\
\hline & & how to, the reader response or interpret the work, and.... and then \\
\hline & & the deconstructionist criticism is focus on the languages that \\
\hline & & author use in this work \\
\hline
\end{tabular}

Mr. Steven was discussing approach and theory in his literary criticism lecture (line 338). In lines 339-340, he invited the student to share their thoughts. After the 
invitation, a student raised her hand (line 341) and the lecturer mentioned her name, indicating the he allowed her to speak (line 342). After that, the student directly gave a long response (lines 343-351). This showed that Mr. Steven provided space and time for the students to express theirideas.

\section{DISCUSSION}

This study examined the use of interaction management strategies in English literature lectures in university setting in Indonesia. The emergent themes have indicated that all lecturers used a number of common interaction management strategies, consisting of code, emotional, and managing strategies.

In terms of code strategies, they used English as the language of instruction during the lectures in the beginning, main, and end part of the lectures. Pennycook (1994) states that in learning situated in a non-native environment with non-native lecturers teaching non-native students, the more target language use the better. Shi (2013) even underlines that the use of target language can improve lingustic capability of students, especially vocabulary technical terms. Since all lectures require the use of English as the medium of instruction, this also indicates that the lecturers are competent communicators (Kuswoyo et al., 2020; Mahmud, 2017; Marsella, 2020; Soraya, 2020).

In terms of emotional strategies, the lecturers used non-verbal gestures and humours or jokes. Jones (2007) asserts that the use of body gestures encourage students to be more active as they enliven interaction. Even though non-verbal communication like body gestures can be universal and local (Amir et al. 2017), but Singelis (1994) believes that the use of non-verbal communication like body gestures has critical role to compliment verbal language (Knapp et al., 2014). Meanwhile, humours or jokes are helpful in engaging the lecturer with the students and creating a relaxed learning atmosphere. The use of humour also increases students' motivation (Akbar et al., 2019; Bakar \& Kumar, 2019; Lovorn \& Holaway, 2015; Tunnisa et al., 2019).

Finally, in terms of managing strategies, the lecturers decided topic, controlled or switched the topic of discussion, decided who speaks, gave direction or commanded the students, gave extended wait time, and offered opportunity for students student speak. Domizio (2008) and Rido et al. (2017) state that announcement of the topic of lesson is important in the introductory part of lecture so the students know what to learn. Meanwhile, switching topic of discussion is salient and lecturers need to signal the transition from one topic to another topic or sub-topic by the use of discourse markers so that the students can follow the structure or move of the lecture (Rido, 2010; Walsh, 2011) as this aids comprehension (Kuswoyo et al., 2020; Rido et al., 2017). Next, turn-taking - allocation and student nomination create opportunities for the students to express their ideas and share their voices (Amir \& Jakob, 2020; Namaziandost \& Nasri, 2019; Sulistyorini, 2019). Rido, Ibrahim, and Nambiar (2015) add that this strategy facilitates less confident or shy students to participate as the lecturer allots them a turn. Further, giving direction and command indicates that the lecturers are the navigators of the lectures and the students are under their supervision

Indonesian Journal of EFL and Linguistics, 5(2), 2020 
(Kuswoyo et al., 2020; Rido et al., 2017). Another strategy, extended-wait time gives the students more time to think deeply about the questions and tasks given, resulting a better learning outcomes (Ingram \& Elliott, 2015; Mercer \& Dawes, 2008).

What is clear from the findings is that the lecturers used various interaction management strategies which promoted students' involvement and they approached learning through interactive way. All lecturers also ensured that the students got opportunity to speak, express their personal standpoint, ask question, give response, and discuss in pair or group. In short, all lecturers fostered interaction by encouraging the students to speak and stimulating them with questions and discussions which could improve communication and develop their critical thinking skills.To some extent, the findings of this study are similar to Rido et al. (2017), Shi (2013), and Sirande (2016).

\section{CONCLUSION}

This study investigated interaction management strategies in English literature lectures in Indonesian university setting. The findings revealed that all lecturers used code strategies, emotional strategies, and managing strategies. They used English as the medium of instruction, body gestures, and humours or jokes during the lectures. They also decided topic, controlled or switched the topic of discussion, decided who speaks, gave direction or commanded the students, gave extended wait time, and offered opportunity for students to speak. All interaction management strategies were used by the lecturers for clarity in the opening, main, and closing parts of the lectures so that the students could understand the materials at hand. The use of the strategies were able to invite participation, to increase student's motivation, and to create conducive learning environment. The strategies also enabled the students express their ideas and engage with the lectures.

To conclude, the use of interaction management strategies made all lecturers occupied more interactional space of the lectures, but the students still had the opportunities to contribute their ideas. By using the interaction management strategies, the lecturers also successfully navigated the distribution of participation as well as content of the lessons. Thus, lecturers should manage the turn-taking and give the students chances to speak. Students will have interactional space and freedom in both what they say and when they say it, but still under the lecturers' close supervision

\section{REFERENCES}

Akbar, N. I. S., Mahmud, M., \& Salija, K. (2019). A Comparative Study on Jokes Expressed by Male and Female Teachers in EFL Classroom Interaction. CORE, $1-12$.

Amir, H. S., \& Jakob, J. C. (2020). Male and Female Teachers' Turn Taking Strategies in EFL Classroom Interaction. International Journal of Progressive Sciences and Technologies (IJPSAT), 19(1), 176-182.

Amir, N. A., Mahmud, M., \& Haryanto. (2017). Male and Female Teachers'

Indonesian Journal of EFL and Linguistics, 5(2), 2020 
Akhyar Rido, Heri Kuswoyo, Rameliya Ayu

Nonverbal Communication in EFL Classroom. CORE, 1-10.

Bakar, F., \& Kumar, V. (2019). The Use of Humour in Teaching and Learning in Higher Education Classrooms : Lecturers' Perspectives. Journal of English for Academic Purposes, 40, 15-25. https://doi.org/10.1016/j.jeap.2019.04.006

Di Gropello, E., Kruse, A., \& Tandon, P. (2011). Skills for the Labor Market in Indonesia. Washington DC: World Bank. https://doi.org/10.1596/978-0-82138614-9

Domizio, P. (2008). Giving a Good Lecture. Diagnostic Histopathology, 14(6), 284288. https://doi.org/10.1016/j.mpdhp.2008.04.004

Hendarman. (2010). Incorporation of Employability Skills in Teaching-Learning Process Within TVE Schools. Proceedings of the 1 St UPI International Conference on Technical and Vocational Education and Training, 301-309.

Ingram, J., \& Elliott, V. (2015). A Critical Analysis of the Role of Wait Time in Classroom Interactions and the Effects on Student and Teacher Interactional Behaviours. Cambridge Journal of Education, 45(3), 1-17. https://doi.org/10.1080/0305764X.2015.1009365

Jefferson, G. (2004). Glossary of Transcript with an Introduction. In G.H. Lerner (Ed.). Conversation Analysis: Studies from the First Generation (pp. 13-31). Amsterdam: John Benjamin.

Jones, L. (2007). The Student-Centered Classroom. Cambridge: Cambridge University Press.

Knapp, M. L., Hall, J. A., \& Horgan, T. G. (2014). Nonverbal Communication in Human Interaction (8th Ed.). Belmont, CA: Wadsworth.

Kuswoyo, H., Tuckyta, E., Sujatna, S., Indrayani, L. M., \& Rido, A. (2020). Cohesive Conjunctions and and so as Discourse Strategies in English Native and NonNative Engineering Lecturers: A Corpus-Based Study. International Journal of Advanced Science and Technology, 29(7), 2322-2335.

Lestari, Y. (2017). Lecturer Talks : Classroom Interaction's Identifying. International Journal of English Language and Teaching, 1(1), 45-49.

Lovorn, M., \& Holaway, C. (2015). Teachers' Perceptions of Humour as a Classroom Teaching, Interaction, and Management Tool. European Journal of Humour Research, 3(4), 24-35. https://doi.org/10.7592/ejhr2015.3.4.lovorn

Mahmud, M. (2017). Communicative Styles of English Students at the State University of Makassar. GEMA Online Journal of Language Studies, 17(February), 223-238.

Marsella, E. (2020). Exploring Teachers' Use of First Language (L1) in EFL Classroom. TEKNOSASTIK, 18(1), 15-24.

Mercer, N., \& Dawes, L. (2008). The Value of Exploratory Talk. In N. Mercer \& S. Hodgkinson (Eds.). Exploring Talk in School: Inspired by the Work of Douglas Barnes (pp. 55-72). London: Sage Publications.

Namaziandost, E., \& Nasri, M. (2019). A Meticulous Look at Long's (1981) Interaction Hypothesis : Does It Have Any Effect on Speaking Skill? Journal of Applied Linguistics and Language Research, 6(July), 218-230. 
Pennycook, A. (1994). The Cultural Politics of English as an International Language (Vol. 13). Longman: London \& New York.

Rido, A. (2010). The Use of Discourse Markers as an Interactive Feature in Science Lecture Discourse in L2 Setting. TEFLIN Journal, 21(1), 90-106.

Rido, A. (2019). What Is Newton's Law of Inertia?: The Use Question in Science Lectures. LITERA, 18(2), 312-325.

Rido, A. (2020a). English for University Graduate Employability: Students and Employers' Voices. Advances in Social Science, Education and Humanities Research, 430, 6-10. https://doi.org/10.2991/assehr.k.200406.002

Rido, A. (2020b). Why They Act The Way They Do?: Pedagogical Practices of Experienced Vocational English Language Teachers in Indonesia. International Journal of Language Education, 4(2), 24. https://doi.org/10.26858/ijole.v4i2.9935

Rido, A., Afrianto, Sari, F. M., Mayangsuri, R. A., \& Duantoro, H. (2017). Discourse Structure of Lecture in L2 in the Indonesian Tertiary Context. Proceedings of the Fifth International Seminar on English Language and Teaching (ISELT), 11-20.

Rido, A., Ibrahim, N., \& Nambiar, R. M. K. (2015). Interaction Strategies of Master Teachers in Indonesian Vocational Classroom: A Case Study. 3L: The Southeast Asian Journal of English Language Studies, 21(3), 85-98.

Shi, D. (2013). Teacher-Student Interaction in Novel and Poetry Classrooms in the Hong Kong Tertiary Setting. Theory and Practice in Language Studies, 3(11), 1975-1982. https://doi.org/10.4304/tpls.3.11.1975-1982

Simpson, R., Lee, D., \& Leicher, S. (2003). MICASE Manual The Michigan Corpus of Academic Spoken English. Ann Abor, MI: English Language Institute: The University of Michigan.

Singelis, T. (1994). Nonverbal Communication in Intercultural Interactions. In $R$. Brislin \& T. Yoshida (Eds.) Improving Intercultural Interactions (pp.268-294). Thousand Oaks, CA: Sage.

Sirande, N. (2016). Turn Taking in Teaching English at English Study Program of FKIP UKI Toraja. Tefl Overseas Journal, 101-119.

Solheim, K. (2019). Teachers' Aspirations to Improve Their Classroom Interaction. International Journal of Learning, Teaching and Educational Research, 18(6), 147-169. https://doi.org/10.26803/ijlter.18.6.9

Soraya. (2020). The Dimension of Discourse in English Class of Higher Education. Indonesian Journal of EFL and Linguistics, 5(1), 195-210.

Sulistyorini, L. (2019). An Analysis of Teacher Interaction Strategies: A Case Study in English Massive Program in Kediri. Language-Edu, 8(1), 1-11.

Tunnisa, D., Mahmud, M., \& Salija, K. (2019). Investigating Teacher's Sense of Humor in Indonesia. International Journal of Language Education, 3(2), 99-114.

Walsh, S. (2011). Exploring Classroom Discourse: Language in Action. London: Routledge. https://doi.org/10.4324/9780203827826

World Bank. (2010). Indonesia Jobs Report towards Better Jobs and Security for All. Jakarta: World Bank. 